\title{
Factors influencing the distribution of Myxobolus cerebralis, the causative agent of whirling disease, in the Cache la Poudre River, Colorado
}

\author{
M. Brady Allen*, Eric P. Bergersen ${ }^{* *}$ \\ Colorado Cooperative Fish and Wildlife Research Unit ${ }^{1}$, Room 201 Wagar Building, Colorado State University, \\ Fort Collins, Colorado 80532, USA
}

\begin{abstract}
Oligochaetes, triactinomyxons (TAMs), and age-0 trout were sampled in the upper Cache la Poudre River, Colorado, to determine the distribution of Myxobolus cerebralis during 1997 and 1998. Densities of the intermediate host, the oligochaete Tubifex tubifex, were 3.5 orders of magnitude higher in the $M$. cerebralis-infected Poudre Rearing Unit (PRU) trout rearing ponds than at any of the river sampling reaches. Oligochaetes, including $T$. tubifex, were rare in the river (1 oligochaete $\mathrm{m}^{-2}$ ), except in a few stream side alcoves and eddies (50 oligochaete $\mathrm{m}^{-2}$ ). Species composition of oligochaetes in the river reaches was more diverse than in the PRU. Tubifex tubifex constituted $50 \%$ or less of the oligochaete community in the river and $98 \%$ in the PRU. Infection rates of T. tubifex were $1 \%$ in the area above the PRU, $2 \%$ in the PRU, and $6 \%$ below the PRU. An increased $M$. cerebralis intensity of infection in age- 0 trout below the PRU could not be attributed entirely to the high numbers of TAMs in its effluent (3.7 TAMs $\mathrm{T}^{-1}$ ). Low densities of TAMs ranging from 0 to $0.2 \mathrm{TAMs}^{-1}$ were found in the river reaches, yet nearly all of the age-0 trout were infected soon after emergence. This suggests that very few TAMs, as measured by filtration, need be present in the water column to bring about infection in the majority of trout present. This also indicates that the parasite can persist and potentially cause reduced juvenile trout recruitment in cold, oligotrophic, sediment poor, highgradient streams.
\end{abstract}

KEY WORDS: Salmonid whirling disease $\cdot$ Myxobolus cerebralis $\cdot$ Tubifex tubifex $\cdot$ Trout rearing unit

\section{INTRODUCTION}

Myxobolus cerebralis, the myxosporean parasite that causes whirling disease (WD), has been implicated in several rainbow trout Oncorhynchus mykiss population declines in the Rocky Mountains (Bergersen \& Anderson 1997). While it had been found in wild trout in many areas throughout the world, it was generally considered to be a problem only in fish culture facilities (Lom 1987). It was not until M. cere-

\footnotetext{
*Present address: US Geological Survey, 5501a CookUnderwood Rd., Cook, Washington 98605, USA

${ }^{* *}$ Corresponding author. E-mail: ericb@cnr.colostate.edu

${ }^{1}$ Cooperators are the US Geological Survey, the Colorado

Division of Wildlife, and Colorado State University
}

bralis spread to the Rocky Mountains in the late 1980s that it became evident that this parasite could adversely affect wild trout populations. The disease is now considered a major threat to survival of wild rainbow trout in the intermountain western USA (Hedrick et al. 1998). Severe declines in recruitment of age-1 rainbow trout have been associated with the presence of $M$. cerebralis in some of Montana and Colorado's best trout streams including Rock creek, Willow creek, and the Madison river in Montana, and the Colorado, Gunnison, South Platte, Rio Grande, and Cache la Poudre rivers in Colorado (Walker \& Nehring 1995, Nehring 1996, Vincent 1996, Baldwin et al. 1998). In Colorado, over 300 sites in 14 of 15 major drainages have tested positive for the parasite (P. G. Walker, Colorado Division of 
Wildlife, pers. comm.). Rainbow trout populations in at least $370 \mathrm{~km}$ of stream have been affected (Nehring et al. 1998).

Myxobolus cerebralis was first described in Germany in 1893 (Hoffman 1990). Though it is believed to be endemic to Europe (Hedrick et al. 1998), it was not detected until rainbow trout, imported from the USA to a German trout rearing facility, displayed classic WD signs (Hoffman 1990). The mechanism of infection remained unknown for almost a century until Markiw $\&$ Wolf (1983) found that tubificid worms were a necessary alternate host for the parasite. Antigenic and genetic evidence has since confirmed the relationship between triactinomyxons (TAMs), which are the waterborne, fish-infective stage of the parasite, and the myxospore, which infects Tubifex tubifex (Markiw 1989, Andree et al. 1997). The oligochaete host for $M$. cerebralis is apparently restricted to $T$. tubifex; attempts to infect other oligochaete species with $M$. cerebralis myxospores have been unsuccessful (Wolf et al. 1986, El-Matbouli \& Hoffman 1989, Hedrick et al. 1996, Hedrick et al. 1998).

Myxobolus cerebralis was first detected in the Cache la Poudre River in 1988 (Nehring 2000). Drastic declines in the number of age-1 wild rainbow trout became evident in the early 1990s at 4 different monitoring stations in a $30 \mathrm{~km}$ reach of the river. In 1995, 5 yr after reductions in recruitment began, age-1 rainbow trout recruitment was nonexistent at the 4 study sites, and overall rainbow trout numbers were severely reduced (Nehring 1996). While rainbow trout biomass has dwindled, the brown trout Salmo trutta biomass has compensated to some degree. Total trout biomass is about the same as before WD, but brown trout now dominate (Puttmann 1996).

The objectives of this study were to (1) determine the oligochaete distribution, density, species composition, and Tubifex tubifex infection rate within the upper Cache la Poudre River; (2) estimate the TAM density within each study reach and determine whether a seasonal or daily cycle of TAM release occurred; and (3) assess the prevalence of Myxobolus cerebralis and overall health of age- 0 rainbow and brown trout in the upper Cache la Poudre River.

\section{Study area}

The Cache la Poudre River, in Larimer County, Colorado, is a tributary of the South Platte River. From its source at an elevation of $3279 \mathrm{~m}$ in Rocky Mountain National Park, it traverses about $112 \mathrm{~km}$ of the eastern slope of the Rocky Mountains before entering the plains (elevation $1525 \mathrm{~m}$ ) near Fort Collins (Fig. 1).
Sixteen kilometers of the Cache la Poudre River is managed by the Colorado Division of Wildlife for wild trout. All brown trout in the drainage are naturally reproducing, and they have not been stocked since the turn of the 19th century, except for one occasion in 1974. During the study period (1996 to 1998), rainbow trout were stocked annually as fingerlings (about $10 \mathrm{~cm}$ ) throughout the river. During this period, catchable-size (about $25 \mathrm{~cm}$ ) Myxobolus cerebralisinfected rainbow trout were also stocked annually in Chambers Lake, a headwater impoundment, and in the most downstream study reach. A majority of the wild trout-managed section is below the Poudre Rearing Unit (PRU). Rainbow trout in this rearing unit first tested positive for M. cerebralis in 1988. In 1998 it produced 350000 catchable rainbow trout that may have been infected with $M$. cerebralis. This facility diverts water directly from the river via a diversion dam into a water supply pond. Water then travels from the pond through a culvert to 6 earthen-bottom trout rearing ponds totaling 3.25 ha of fine substrate. Finally the water flows to a settling pond and is discharged directly back to the river.

The Cache la Poudre River has several headwater impoundments and trans-basin diversions but no large mainstem reservoirs. Because of this, it maintains the illusion of a wild mountain river and it is Colorado's only federally designated National Wild and Scenic River. The annual flow pattern was similar to the historical pattern and the river continues to have high annual spring flows. However, annually April to June flows were reduced by about $10 \%$, July to September flows were increased by about $10 \%$, and November to March flows were increased by about $50 \%$ as a result of water manipulation (P. Weiss, City of Fort Collins Water Utilities, pers. comm.). Flows in the river can range from $0.42 \mathrm{~m}^{3} \mathrm{~s}^{-1}$ during the winter to over $56 \mathrm{~m}^{3} \mathrm{~s}^{-1}$ and as much as $115 \mathrm{~m}^{3} \mathrm{~s}^{-1}$ during spring runoff, which typically peaks in June. The average water temperature from April to November in the study area was $9.0^{\circ} \mathrm{C}$ with a maximum of $17.9^{\circ} \mathrm{C}$ and a minimum of $-0.1^{\circ} \mathrm{C}$. Extensive anchor ice forms during the winter in all reaches, usually from November through March, and it is particularly troublesome in November and early December.

Rainbow trout and brown trout are the principal game fish in the Cache la Poudre River, but brook trout Salvelinus fontinalis, finespotted Snake River cutthroat trout Oncorhynchus clarki, and mountain whitefish Prosopium williamsoni are present in low numbers. Small numbers of longnose suckers Catostomus catostomus, longnose dace Rhinichthys cataractae, and rarely a white sucker Catostomus commersoni are also present. 

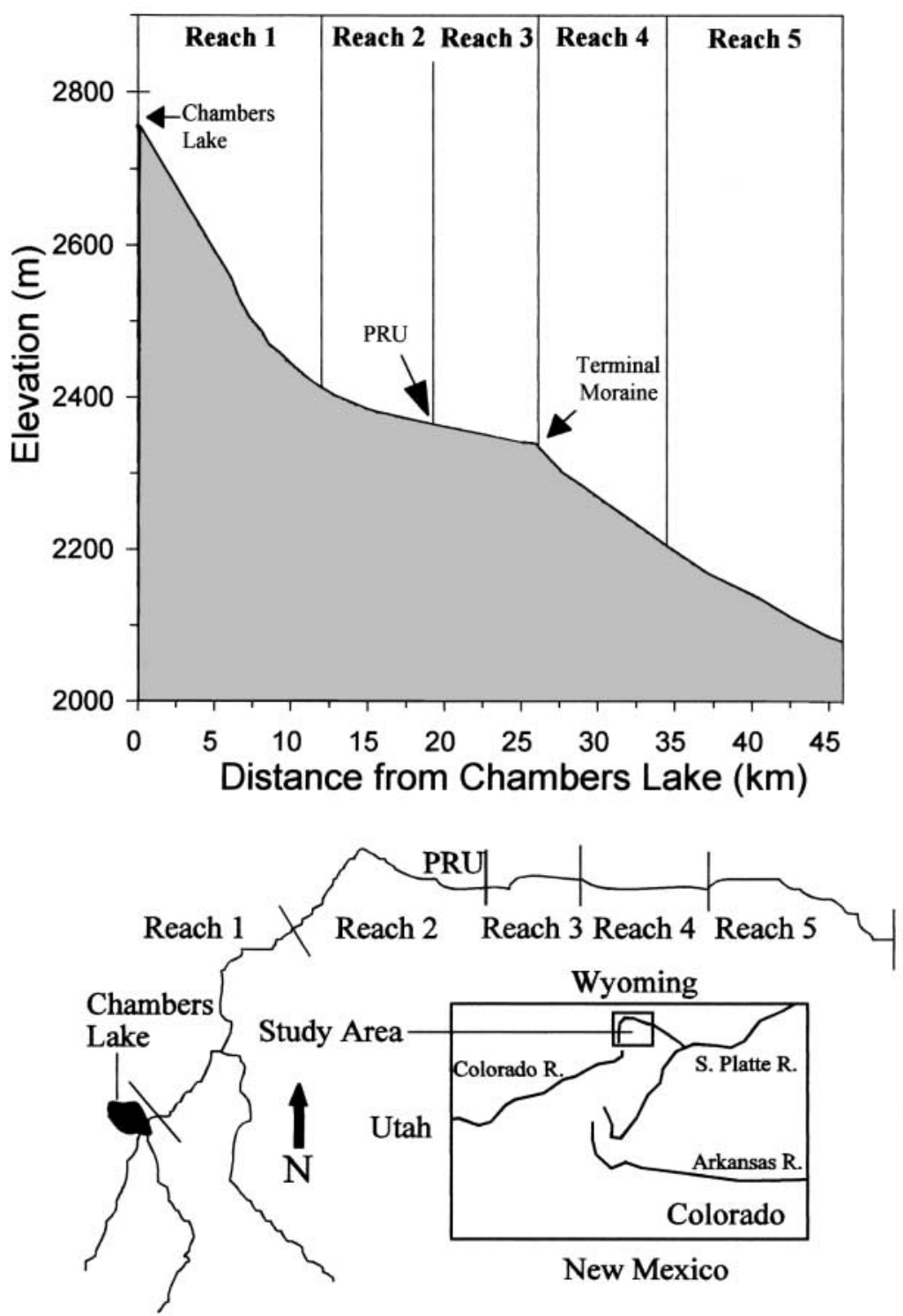

Fig. 1. Elevation, gradient, and study reaches of the Cache la Poudre River, Colorado, over which oligochaetes, triactinomyxons, and fish were sampled during 1997 to 1998. PRU: Poudre Rearing Unit location

extended from below the rearing unit to the terminal moraine. Reach 4 extended $10 \mathrm{~km}$ below the terminal moraine, and the Reach 5 extended $10 \mathrm{~km}$ below Reach 4 .

\section{METHODS}

Water samples collected in each reach, 4 times per year, were analyzed for biological oxygen demand (BOD), alkalinity, total dissolved solids (TDS), $\mathrm{pH}$, and conductivity in 1997 and 1998. These sampling occasions coincided with winter before ice-up, with spring after ice-off, with summer during peak flow, and with fall during low flow. Thermographs were placed in all study reaches from May to October 1998.

Oligochaetes. In spring 1997, randomized transects were sampled in each study reach to collect oligochaetes; however, no tubificids were found. Based on this, it was determined that the benthic sampling effort would have to be concentrated in the best available tubificid habitat (i.e. low current velocity, sand, silt, or clay substrate, and areas of organic debris accumulation). Random locations were selected in each reach, and the finest substrate in that location was sampled. Core sampling, to determine density and species composition, was conducted in all areas except where substrate prohibited its use. In study Reaches 1, 4, and 5, where only larger substrate could be found, benthic samples were collected with a $500 \mu \mathrm{m}$ mesh kick net by rolling large boulders and disturbing the substrate behind and underneath the boulder

For this study the Cache la Poudre River was divided into 5 reaches according to geographical and physical characteristics (Fig. 1). There is a terminal moraine in the river canyon about $5 \mathrm{~km}$ downstream of the PRU. The retreating glacier left fine gravel, sand, and silt entrapped in the flood plain for about $15 \mathrm{~km}$ upstream. This meandering meadow reach has a reduced gradient and contains more evidence of beaver (Castor canadensis) activity than elsewhere along the river. The substrate in the remainder of the river consists of coarse gravel, cobble, and boulders. Reach 1 was from the headwater impoundment to the upper end of the glacial deposit. Reach 2 was from the upper end of the glacial deposit to just above the rearing unit. Reach 3 with a small shovel to a depth of about $0.3 \mathrm{~m}$. In study Reaches 2 and 3, with finer substrate available in alcoves, eddies, and the PRU, an $18.32 \mathrm{~cm}^{2}$ core sampler was used to collect 5 replicate samples at each site. In the PRU, benthic sampling was random because all the rearing ponds contained fine substrates suitable for core sampling. Benthic samples were collected and preserved in ethanol or formalin in spring 1997 and 1998 before runoff, and fall 1997 before ice-up. Benthic samples were also collected in Reaches 2, 3, and the PRU, using core samples, every 3 wk from spring 1997 to spring 1998 to assess oligochaete maturity. Core samples were washed on a $500 \mu \mathrm{m}$ mesh screen; practically no oligochaetes were 
observed to pass through mesh of this size. A large proportion of the oligochaetes collected consisted of small or immature specimens.

Oligochaetes were mounted on microscope slides with CMCP10 mounting media (Polysciences) and mature tubificids were identified to species according to Brinkhurst (1986). All other oligochaetes were identified to family. Immature tubificids were separated by chaetal number, location, and form (simple pointed, bifid, or hair and pectinate) and then assigned to species based on the proportion of identifiable mature tubificids present in the sample (Brinkhurst 1986). This method assumes similar age class distributions among species. For each sample a total count was first determined, and then a subsample of 100 oligochaetes was taken for identification.

Oligochaete samples within each study reach were pooled, and differences in densities between study reaches were evaluated using an analysis of variance (ANOVA). Data were log-transformed to create homogeneous variances. Tukey's studentized range test was used to account for multiple comparisons of densities between reaches. A chi-squared test of equality of proportions was used to assess the differences between reaches in the proportion of the oligochaete communities that were Tubifex tubifex. Differences in T. tubifex proportions and total oligochaete densities were considered significant at the $\alpha=0.05$ level.

Additional oligochaetes were collected in May 1998 from all reaches to determine the Myxobolus cerebralis infection rate in Tubifex tubifex. To achieve this, the tubificids with hair chaetae were separated from other oligochaetes in the samples. We assumed that nearly all haired tubificids were $T$. tubifex because $T$. tubifex comprised over $99 \%$ of the positively identified haired oligochaetes. Sixteen of these individual haired oligochaetes were treated as a single composite sample for the analysis of $M$. cerebralis infection rates. Up to 100 samples of 16 oligochaetes each were collected from each reach where available. The number of individuals per composite sample (n) was determined by running computer simulations of the first equation below, which is based on the binomial distribution, using infection rates ranging from 0.5 to $10 \%$. The optimum $\mathrm{n}$ was determined by choosing a value that provided the smallest standard error over the range of potential infection rates. This composite sampling technique was used because infection levels were assumed to be low (based on Markiw 1986 and Wolf et al. 1986) and testing each individual T. tubifex was cost prohibitive. These composite samples were analyzed by a single-round polymerase chain reaction (PCR) assay described in Schisler et al. (2001) to determine the presence of $M$. cerebralis DNA, using a modification of the technique described by Andree et al. (1998).
The proportion of infected Tubifex tubifex was calculated using composite sampling statistics (Zendt \& Bergersen 2000). Infection rates were calculated using the equation given by Boswell \& Patil (1987):

$$
\hat{p}=1-\left(1-p_{\mathrm{m}}\right)^{1 / \mathrm{n}}
$$

where $\hat{p}$ is the unknown prevalence of infection, $\mathrm{n}$ is the number of individuals per composite sample, $\mathrm{m}$ is the number of composite samples, and $p_{\mathrm{m}}$ is the proportion of the composite samples that were positive for Myxobolus cerebralis DNA. The standard error used for calculation of $95 \%$ confidence intervals was estimated by:

$$
\operatorname{se}(\hat{p})=\sqrt{\frac{1}{\mathrm{n}^{2} \mathrm{~m}}\left(\frac{p_{\mathrm{m}}}{\left(1-p_{\mathrm{m}}\right)^{\frac{\mathrm{n}-2}{\mathrm{n}}}}\right)}
$$

Triactinomyxons. TAMs were collected using a battery-powered bilge pump and a $20 \mu \mathrm{m}$ Nitex mesh, a minimum of 3 times in all study reaches. This filtration method is similar to that used by Thompson \& Nehring (2001). Water was pumped using the bilge pump from about $15 \mathrm{~cm}$ above the substrate into a cone-shaped Nitex filter housed in a $114 \mathrm{l}$ container. Filtered water was released from the container from 2 valves located at the base. This arrangement allowed water to be filtered through the net with filtered water outside the net acting to reduce hydrostatic pressure and damage to the TAMs. About $3000 \mathrm{l}$ of river water was concentrated to $130 \mathrm{ml}$ every $1.5 \mathrm{~h}$. Filtrates were thoroughly stirred and allowed to settle for about $30 \mathrm{~s}$. Twenty-two milliliter samples were then drawn from the filtrate and stained with $120 \mu \mathrm{l}$ of saturated crystal violet solution. One $85 \mu \mathrm{l}$ aliquot per $2 \mathrm{ml}$ sample was placed on a $60 \times 15 \mathrm{~mm}$ petri dish with $2 \mathrm{~mm}$ grids and covered with a $22 \times 40 \mathrm{~mm}$ cover slip. TAMs were then counted at $100 \times$ magnification.

On 3 occasions water was filtered in the spillway of Chambers Lake, the headwater impoundment. About $6000 \mathrm{l}$ of water was filtered in $5 \mathrm{~h}$ and condensed to $130 \mathrm{ml}$ on each occasion. Twenty slides were examined for TAMs as described above. Because TAM densities were assumed to be low at this location, more water was filtered for each sample, and portions of the filtrate were tested for the presence of Myxobolus cerebralis DNA by PCR analysis.

On 7 occasions water was filtered from the effluent channel of the PRU, for $1.5 \mathrm{~h}$ every $2 \mathrm{~h}$, for a total period of $24 \mathrm{~h}$, to determine any seasonal and diel cycle of TAM release. The filtration method was the same as described above with about $3000 \mathrm{l}$ filtered in $1.5 \mathrm{~h}$, which was about $0.3 \%$ of the total effluent flow.

Fish. From July to November 1997 and 1998 an attempt was made to collect 10 age- 0 rainbow and brown trout with a backpack electrofishing unit 
every 2 wk in each reach. The fish were euthanized with a lethal dose of MS-222, measured, and examined for the presence of gas bubbles behind the eyes and in the gill filaments. The gill arches were then excised, mounted on microscope slides, and viewed at $100 \times$ magnification, and the ectoparasites were identified and enumerated. Gas bubble trauma and ectoparasite infection were examined to estimate the influence of other stressors on the fish. In November 1997, before ice-up, an attempt was made to collect an additional 10 age0 rainbow trout and 10 age- 0 brown trout from each reach to determine the proportion of fish infected with Myxobolus cerebralis. A total of 84 fish were collected by electrofishing and euthanized. After lengths and weights were obtained, we visually inspected fish for WD signs such as black tail, spinal and cranial deformities, or whirling behavior. Each fish was preserved separately in $70 \%$ ethanol and used in a single-round PCR assay, described in Schisler et al. (2001), to assess the presence and relative amount of $M$. cerebralis DNA. Although this PCR assay is not a quantitative technique, it did provide order-of-magnitude differences in the amount of $M$. cerebralis DNA initially in the sample (Lie \& Petropolous 1998, J. Wood, Pisces Molecular, unpubl. data). This was accomplished by subjectively scoring the amplicon band intensities into 1 of 5 categories: negative, weak positive, positive, strong positive, and very strong positive. Amplicon band intensities were determined by comparison to amplicons from positive and weak positive control templates with standardized DNA concentrations. These subjective scores were found to be similar between 2 independent individual scorings and were reproducible when repeated in another PCR run. Schisler et al. (2001) also found a highly significant correlation between the PCR band strength intensity and myxospore counts from the same fish, using the more traditional pepsin-trypsin digest method (Markiw \& Wolf 1974). In 1998 a total of 350 age-0 trout were collected to determine $M$. cerebralis infection levels by PCR analysis using the same method described above. Logistic regression, with backwards model selection and a saturated model with length, weight, date collected, reach collected, and all interactions, was used to analyze the fish PCR results. Rainbow and brown trout were tested separately, and positive or negative PCR results were used as the response variable (not amplicon band intensities).

\section{RESULTS}

During the ice-free season (May to October), water chemistry was similar between reaches (Table 1). The presence of tubificids was related to differences in gradient and associated fine substrate availability between reaches. Mean temperatures were near the optimum for TAM development and longevity, and maximum temperatures never exceeded the requirements for viability of Tubifex tubifex, TAMs, or their developmental stages (El-Matbouli et al. 1999).

\section{Oligochaetes}

Less than $5 \%$ of the individuals in the oligochaete samples taken every $3 \mathrm{wk}$ in summer and fall of 1997 were mature, making positive identification of tubificids in those samples difficult. The highest maturity levels (30 to $100 \%$ ) occurred in the spring before runoff. This cycle of maturity was also noted in some Montana streams (Dan Gustafson, Montana State University, pers. comm.). Therefore, 57 benthic samples were taken for oligochaete identification and Tubifex tubifex infection rates in spring 1998; 13000 oligochaetes were collected, 2500 were identified (including 1314 T. tubifex), and 6000 were tested for the presence of Myxobolus cerebralis DNA by PCR analysis.

Oligochaetes were not randomly distributed among reaches (ANOVA; p < 0.0001; Table 2). Mean densities in Reaches 2 and 3 were not different from each other ( $p=0.97$ ), but they were significantly different from all other reaches $(\mathrm{p}<0.05)$. Reaches 1,4 , and 5 were not different from each other $(p=0.99)$ but contained significantly lower oligochaete densities than the other reaches $(\mathrm{p}<0.05)$. The earthen-bottom 
Table 2. Back-transformed log mean oligochaete density with $95 \%$ confidence intervals (CI), percentage of the oligochaetes that were Tubifex tubifex, and percentage of $T$. tubifex infected with Myxobolus cerebralis, with 95\% CI at each study reach on the Cache la Poudre River and the Poudre Rearing Unit (PRU). Means without superscript letters in common are significantly different based on Tukey's studentized range test. -: sample size was too small for this analysis

\begin{tabular}{|lccc|}
\hline Reach & $\begin{array}{c}\text { Oligochaetes } \mathrm{m}^{-2} \\
(95 \% \mathrm{CI})\end{array}$ & $\begin{array}{c}\text { T. tubifex } \\
(\%)\end{array}$ & $\begin{array}{c}\text { Infected } \\
\text { T. tubifex } \\
(\%, \pm 95 \% \mathrm{CI})\end{array}$ \\
\hline 1 & $0.3^{\mathrm{z}}(0-5)$ & 11 & - \\
2 & $52^{\mathrm{y}}(15-201)$ & 43 & $1.2 \pm 0.7$ \\
PRU & $162500^{\mathrm{x}}(43000-620000)$ & 98 & $2.1 \pm 0.4$ \\
3 & $51^{\mathrm{y}}(13-195)$ & 57 & $6.0 \pm 2.0$ \\
4 & $1.2^{\mathrm{z}}(0-16)$ & 38 & - \\
5 & $1.2^{\mathrm{z}}(0-12)$ & 39 & - \\
\hline
\end{tabular}

Table 3. Triactinomyxon (TAM) densities of water filtrations during 1997 to 1998 at each study reach on the Cache la Poudre River and $24 \mathrm{~h}$ filtrations at the PRU

\begin{tabular}{|c|c|c|c|c|c|}
\hline Reach & Samples & Years & 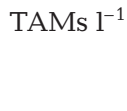 & $\begin{array}{c}\text { Range } \\
\left(\text { TAMs l-1) }^{-1}\right)\end{array}$ & $\begin{array}{l}\text { Amount } \\
\text { filtered } \\
\text { (l) }\end{array}$ \\
\hline 1 & 3 & 1998 & $0^{\mathrm{a}}$ & 0 & 18400 \\
\hline 2 & 4 & 1997-1997 & 0 & 0 & 18000 \\
\hline PRU & 10 & 1997-1998 & 3.7 & 0.04 to 11 & 174100 \\
\hline 3 & 3 & 1997-1998 & 0.1 & 0 to 0.2 & 8400 \\
\hline 4 & 3 & 1998 & 0.1 & 0 to 0.2 & 7600 \\
\hline 5 & 5 & 1997-1998 & 0.04 & 0 to 0.2 & 14200 \\
\hline \multicolumn{6}{|c|}{$\begin{array}{l}\text { aSamples tested by polymerase chain reaction (PCR) con- } \\
\text { tained Myxobolus cerebralis DNA }\end{array}$} \\
\hline
\end{tabular}

ponds at PRU supported significantly higher densities than all river reaches $(\mathrm{p}<0.0001$; at times portions of the substrate appeared red with oligochaetes). The proportion of Tubifex tubifex infected with Myxobolus cerebralis in Reach 3 was significantly higher than that in Reach 2 or the PRU ( $p=0.01$; Table 2). Low sample size prevented PCR testing of $T$. tubifex in Reaches 1,4 , and 5.

There were only 3 species of Tubificidae positively identified in the Cache la Poudre River: Tubifex tubifex, Limnodrilus hoffmeisteri, and a single Ilyodrilus templetoni. In addition, various taxa of the families Naididae, Enchytraeidae, and Lumbriculidae were present in all reaches except the PRU (Fig. 2). Compared to the PRU, all the river reaches had a significantly smaller proportion of the sampled oligochaete community that was $T$. tubifex $(\mathrm{p}<0.001)$.

\section{Triactinomyxons}

No TAMs were found above the PRU by microscopic examination of filtered water (Table 3). All 3 water samples from the spillway of Chambers Lake were positive for Myxobolus cerebralis DNA by PCR analysis, even though no TAMs were found by microscopy, indicating that TAMs were present in the filtrates at densities less than $0.02 \mathrm{TAMs}^{-1}$. The effluent of the PRU had an average of $3.7 \mathrm{TAMs}^{-1}$. Below the PRU, TAMs were rarely counted and averaged 0.07 TAMs $l^{-1}$.

The first three $24 \mathrm{~h}$ TAM filtrations in the fall of 1997 at the PRU effluent channel suggested that a diel cycle of TAM release might exist, with a peak release at around 04:00 h (Fig. 3). The following 4 filtrations occurred during the winter, spring, and summer. There was a reduced number of TAMs $\mathrm{l}^{-1}$ during the winter and spring. However, low numbers of TAMs were also recorded in the fall $1 \mathrm{yr}$ after the possible daily cycle was recorded, with no pattern evident.

\section{Fish}

Mild ectoparasite infections were recorded in $10 \%$ of the 158 age- 0 rainbow and brown trout sampled in summer 1997. The ectoparasites identified in order of occurrence were Trichodina, Chilodonella, Apiosoma, and Epistylis spp. Two percent of the fish had gas bubble emboli in the gill filaments and $10 \%$ had gas bubbles behind the eyes, but no WD signs were observed. Seventy-nine of the 84 age-0 rainbow and brown trout collected and tested by PCR analysis in

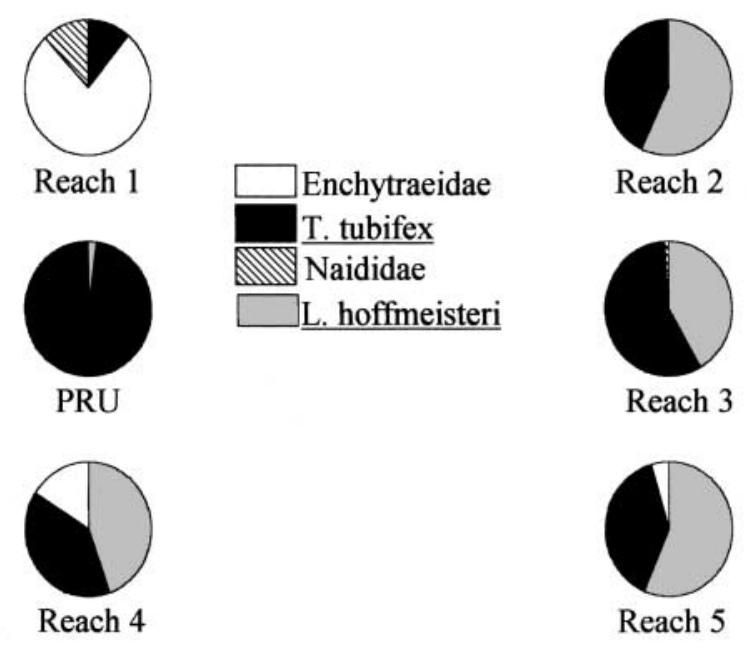

Fig. 2. Species composition of oligochaetes sampled at 6 study sites on the Cache la Poudre River, Colorado, during 1997 to 1998 
November 1997 were positive for Мухоbolus cerebralis DNA even though no WD signs were observed. All of the negative fish were brown trout, and $83 \%$ of the negative fish were collected in Reach 1. Fish with the highest mean PCR band intensity were collected directly below the PRU.

In $1998,94 \%$ of 328 age- 0 rainbow and brown trout in all reaches were positive for Myxobolus cerebralis, many of which had fork lengths as small as $23 \mathrm{~mm}$. Date and reach collected were not significant variables determining fish infection rate. Fork length was the only significant variable in the logistic regressions for rainbow $(\mathrm{p}=0.04)$ and brown trout $(\mathrm{p}=0.001)$. Mean fork length of the 20 uninfected fish collected was $30 \mathrm{~mm}$ (range 23 to 51). Only 2 uninfected rainbow trout were collected, one in Reach 2 with a fork length of $24 \mathrm{~mm}$ and one in Reach 5 with a fork length of $25 \mathrm{~mm}$. Nine of the uninfected brown trout were collected in Reach 2, 4 in Reach 4, and 5 in Reach 5. No uninfected fish were found in Reaches 1 or 3 in 1998. WD signs were never observed in any of the trout collected. Based on the relationship between PCR amplicon band intensity and the amount of parasite DNA in the sample, trout below the PRU were more heavily infected with $M$. cerebralis than those in all other reaches (Fig. 4).

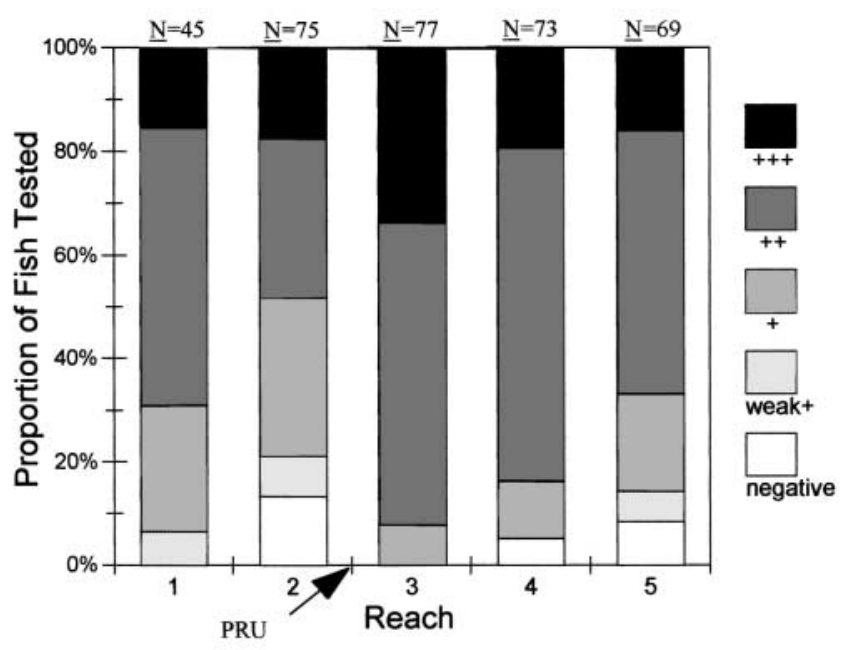

Fig. 4. Young of the year trout infection levels by study site based on polymerase chain reaction (PCR) band intensity for a single round PCR assay in the Cache la Poudre River, Colorado, during July to September of 1998. The legend $(+++,++$, + , weak+, negative ) refers to the PCR band strength intensity and therefore original parasite DNA concentrations in each fish sampled. The sample size is indicated by an $\underline{\mathrm{N}}$ at the top of each bar

\section{DISCUSSION}

Tubifex tubifex was found throughout the upper $45 \mathrm{~km}$ of the Cache la Poudre River; however, it was rare in all but a few sites and the PRU. Initially, randomized sampling yielded many oligochaetes but no tubificids, except in the PRU. Later sampling was concentrated in what we considered the most likely $T$. tubifex habitat, and they were still difficult to find. For example, in Reach 1, 11 benthic samples were collected, of which 7 had oligochaetes present, but only 2 contained $T$. tubifex. This pattern was similar in Reaches 4 and 5. When sampling Reaches 2 and 3, the main river channel had few T. tubifex, but the small substrate pockets and side channels had relatively high densities of T. tubifex and Limnodrilus spp. In contrast, every benthic sample in the PRU contained thousands of $T$. tubifex. Oligochaete densities in the PRU were 3.5 orders of magnitude higher than in the alcoves and eddies in Reaches 2 and 3. Almost all of those oligochaetes were T. tubifex. In most other areas, less than half of the oligochaete community was $T$. tubifex. This is noteworthy because recent evidence suggests that oligochaete strains and species that are not susceptible to Myxobolus cerebralis infection can ingest and inactivate the myxospores, reducing the number of TAMs released into the water column (Hedrick et al. 1998, M. El-Matbouli, University of Munich, pers. comm.).

The Tubifex tubifex infection rates of 1.2 to $2.1 \%$ found in Reach 2 and the PRU were similar to infection rates ranging from 0.6 to $2.6 \%$ reported elsewhere 
(Markiw 1986, Wolf et al. 1986, Rognlie \& Knapp 1998, Zendt \& Bergersen 2000). It may be that some proportion of the T. tubifex population in the PRU is a strain resistant to infection, or the sheer numbers of tubificids in the rearing ponds may have been sufficient to keep the infection rate relatively low. The infection rate of $6 \%$ in Reach 3 below the PRU was significantly higher than what was found in Reach 2 or the PRU itself. We estimated that the rearing unit had about 3.5 billion myxospores being released annually as a result of the $10 \%$ mortality in the 350000 trout present (averaging 100000 myxospores per fish; A. Ganek, Colorado Division of Wildlife, pers. comm.). If some portion of these were able to exit the PRU via the effluent without contacting the substrate, they could have settled in the alcoves and eddies downstream where T. tubifex could ingest them and become infected. Unfortunately, no methods were available for the field collection of myxospores free of fish skeleton to determine if they were indeed escaping the PRU's settling pond to infect $T$. tubifex downstream. The increased T. tubifex infection rate may have also been from the decomposing trout that were frequently observed in the same locations of Reach 3 where $T$. tubifex were collected.

Inferences made about the oligochaete infection rates, density, and species composition are limited to one time period because all of the oligochaetes for these analyses were collected in the spring of 1998 between ice-out and runoff. It may be that infection levels would be highest in the spring before runoff because Tubifex tubifex maturity levels were highest so more time was available to ingest spores and become infected. Zendt \& Bergersen (2000) indicated that $T$. tubifex infection rates were highest prior to runoff and decreased over the summer in Willow Creek and the upper Colorado River. It is unknown how species composition and densities of oligochaetes varied over the course of the year in the Cache la Poudre River. We believe that the population in the PRU is relatively constant because these populations do not experience low flow and anchor ice in the winter and snow melt runoff in the spring. The population in the river would vary more over the course of the year due to increased annual variability in flow. Zendt \& Bergersen (2000) found increasing oligochaete density over the summer, but the findings were not significant.

The PRU effluent channel was a point source of TAMs with substantially higher densities being detected here than in any other place in the river. With the exception of the PRU, the filtration technique was not sensitive enough to determine if the TAM densities in the other reaches were different. While filtration efforts failed to indicate the presence of TAMs in the river below Chambers Lake (3 separate filtrations revealed 0 TAMs), water samples collected during these filtrations and tested by PCR all indicated the presence of Myxobolus cerebralis DNA (presumably TAMs). This was in a reach where $94 \%$ of the trout were positive for $M$. cerebralis. Similarly, filtrations in the other reaches often yielded no TAMs, but most of the trout were infected, suggesting that very few TAMs need be present in the water column to bring about infection in the majority of fish present. This also illustrates that the filtration technique was not an appropriate technique for detecting lower densities of TAMs but was useful in locating point sources. Other researchers have concluded that filtering TAMs with $20 \mu \mathrm{m}$ mesh produced inconsistent recovery rates (F. T. Barrows, US Fish and Wildlife Service, pers. comm.). Therefore, the TAM densities measured were probably underestimates of the actual TAM density.

Similar to the cycle found by Thompson \& Nehring (2001), we noted a seasonal cycle in TAM production, with higher densities found in the summer and fall. We also found a diel pattern that had a peak at around 04:00 h. Reduced densities were collected during the winter and spring with no diel pattern evident, possibly because water temperatures were below $5^{\circ} \mathrm{C}$. However, low numbers of TAMs were also recorded 1 yr after the apparent daily cycle was recorded, and no pattern was evident. This may be due to altered rearing unit operations, random fluctuations in the daily or seasonal cycle of TAM release, or inherent variability in the sampling method.

Initially, testing for the presence of Myxobolus cerebralis DNA in age-0 trout by PCR analysis was intended to find differences in the infection rates between rainbow and brown trout by location, fish size, or date sampled. Electrofishing was initiated as soon as the brown trout hatched in late June and continued until it became clear that nearly every fish was positive for $M$. cerebralis regardless of location or species. It should be noted that there were large differences in the timing of emergence depending on species and location. Brown trout emerged in late June below the PRU and about 1 to 2 wk later in the reaches above the PRU. Rainbow trout did not emerge in the lower reaches until early to mid-August, with some individuals smaller than $25 \mathrm{~mm}$ collected in September. No age-0 rainbow trout were ever collected in Reach 1, in which anchor ice formed in November. The fact that many fish as small as $23 \mathrm{~mm}$ were infected suggests that almost all fish in every reach were infected soon after they emerged.

Although most of the trout in all reaches were infected by the time they were large enough to be sampled, neither rainbow trout nor brown trout ever exhibited any clinical signs of WD such as whirling, black tail, or spinal and cranial deformities. Age-0 rainbow trout in the Cache la Poudre River appeared asympto- 
matic, robust, and relatively abundant up to ice-up, but they did not appear to recruit to the population the following year. Age-1 brown trout were almost always found during routine fish collection efforts in every reach, but in contrast, no age-1 rainbow trout were observed in any reach during $2 \mathrm{yr}$ of sampling. The lack of clinical disease in the Cache la Poudre River was in contrast to the upper Colorado River, where many age- 0 trout exhibited clinical signs of WD and where a precipitous decline in age- 0 abundance was noted as the summer progressed (Nehring 1998). The lack of signs and absence of heavy summer and fall mortality in the age-0 rainbow trout in the Cache la Poudre River suggests that the overall severity of Myxobolus cerebralis infection in this population may be less than that reported in the Colorado River and elsewhere (Nehring 1998, Schisler 1999). This difference between drainages may also be because the upper Colorado River also has several other factors influencing age- 0 mortality such as added ectoparasite infections, gas supersaturation, and higher summer temperatures than the Cache la Poudre River.

Although it is clear that the PRU is a major point source for TAMs and Tubifex tubifex, it is less clear how much it affects the wild trout downstream. The trout PCR data (Fig. 4) indicated that all trout collected in Reach 3 were infected, and they had a higher intensity of infection, but it is not known how PCR band strength intensity relates to fish survival. Also, high fish infection rates can occur in the absence of extensive T. tubifex habitat and presumably T. tubifex (i.e. Reaches 1, 4, and 5). Finding any T. tubifex in Reaches 1,4 , and 5 was very difficult, yet almost all of the fish in these areas were infected soon after emergence. This indicates that it takes few T. tubifex and TAMs (as measured by filtration) to produce nearly complete infection of all salmonids in the system and that the parasite can persist in low numbers and still cause reduced juvenile trout recruitment in cold, oligotrophic, sediment-poor, high-gradient streams.

Our study together with the findings of Thomson \& Nehring (2001) supports the conclusion that low velocity, standing, or impounded waters that aggregate and concentrate nutrients and sediments can create optimum habitats for Tubifex tubifex and have great potential to become point sources of Myxobolus cerebralis TAMs. However, there are many physical, chemical, biological, and ecological parameters, known and unknown, that influence a fish population's ability to withstand disease (Snieszko 1974). Disease can directly influence success of reproduction, performance, susceptibility to predation, and other critical factors required for the survival of a species (Hedrick 1998). The dynamic nature of $M$. cerebralis, its oligochaete host, and the complex interactions of habitat components in infected streams may preclude generalizations about how WD manifests itself in any given water. Different stressors in each drainage influence age- 0 survival and dictate that WD management will vary by river and perhaps river reach.

Acknowledgements. We thank the National Partnership on the Management of Wild and Native Coldwater Fisheries for providing the main funding for the project, and the Colorado Division of Wildlife and the Colorado Cooperative Fish and Wildlife Research Unit for additional funding and support. Thanks to Terry James, Brad Neuschwanger, and Joe Zendt for field assistance and to Brett Johnson, Boris Kondratieff, and Pete Walker for reviewing early drafts of this manuscript.

\section{LITERATURE CITED}

Andree KB, Gresoviac SJ, Hedrick RP (1997) Small subunit ribosomal RNA sequences unite alternate actinosporean and myxosporean stages of Myxobolus cerebralis the causative agent of whirling disease in salmonid fish. J Eukaryot Microbiol 44:208-215

Andree KB, MacConnell E, Hedrick RP (1998) A nested polymerase chain reaction for the detection of genomic DNA of Myxobolus cerebralis in rainbow trout Oncorhynchus mykiss. Dis Aquat Org 34:145-154

Baldwin TJ, Peterson JE, McGhee GC, Staigmiller KD and 3 others (1998) Distribution of Myxobolus cerebralis in salmonid fishes in Montana. J Aquat Anim Health 10: 361-371

Bergersen EP, Anderson DE (1997) The distribution and spread of Myxobolus cerebralis in the United States. Fisheries 22:6-7

Boswell MT, Patil GP (1987) A perspective of composite sampling. Commun Stat Theory Methods 16:3069-3093

Brinkhurst RO (1986) Guide to the freshwater aquatic microdrile oligochaetes of North America. Canadian Special Publication of Fisheries and Aquatic Sciences 84, Department of Fisheries and Oceans, Ottawa

El-Matbouli M, Hoffman RW (1989) Experimental transmission of two Myxobolus spp. Developing bisporogeny via tubificid worms. Parasitol Res 75:461-464

El-Matbouli M, McDowell TS, Antonio DB, Andree KB, Hedrick RP (1999) Effect of water temperature on the development, release, and survival of the triactinomyxon stage of Myxobolus cerebralis in its oligochaete host. Int J Parasitol 29:627-641

Hedrick RP (1998) Relationships of the host, pathogen, and environment: implications for diseases of cultured and wild fish populations. J Aquat Anim Health 10:107-111

Hedrick RP, Andree KB, McDowell TS, Gresoviac S (1996) Whirling disease of salmonid fish: an overview of a complex host/pathogen relationship. In: Bergersen EP, Knopf BA (eds) Whirling disease workshop proceedings: where do we go from here? Colorado Cooperative Fish and Wildlife Research Unit, Fort Collins, CO, p 7-14

Hedrick RP, El-Matbouli M, Adkison MA, MacConnell E (1998) Whirling disease: re-emergence among wild trout. Immunol Rev 166:365-376

Hoffman GL (1990) Myxobolus cerebralis, a worldwide cause of salmonid whirling disease. J Aquat Anim Health 2: 30-37

Lie YS, Petropolous CJ (1998) Advances in quantitative PCR technology: 5' nuclease assays. Curr Opin Biotechnol 9: $43-48$ 
Lom J (1987) Myxosporea: a new look at long-known parasites of fish. Parasitol Today 3:327-332

Markiw ME (1986) Salmonid whirling disease: dynamics of experimental production of the infective stage: the triactinomyxon spore. Can J Fish Aquat Sci 43:521-526

Markiw ME (1989) Salmonid whirling disease: myxosporean and actinosporean stages cross-react in direct fluorescent antibody test. J Fish Dis 12:137-141

Markiw ME, Wolf K (1974) Myxosoma cerebralis: isolation and centrifugation from fish skeletal elements: sequential enzymatic digestion and purification by differential centrifugation. J Fish Res Board Can 31:15-20

Markiw ME, Wolf K (1983) Myxosoma cerebralis (Myxozoa: Myxosporea) etiologic agent of salmonid whirling disease require tubificid worm (Annelida: Oligochaeta) in its life cycle. J Protozool 37:2225-2227

Nehring RB (1996) Whirling disease in feral trout populations in Colorado. In: Bergersen EP, Knopf BA (eds) Whirling disease workshop proceedings: where do we go from here? Colorado Cooperative Fish and Wildlife Research Unit, Fort Collins, CO, p 126-144

Nehring RB (1998) Stream fisheries investigations. Colorado Division of Wildlife, Federal Aid Project F-237-R5, Fort Collins, $\mathrm{CO}$

Nehring RB (2000) Whirling disease investigations. Colorado Division of Wildlife, Federal Aid Project F-237-R7, Fort Collins, $\mathrm{CO}$

Nehring RB, Thompson KG, Hebein S (1998) Impacts of whirling disease on wild trout populations in Colorado. In: Wadsworth KG (ed) Trans N Am Wildl Nat Resour Conf 63:82-94

Puttmann S (1996) Balancing two missions: a case study in managing the whirling disease problem. In: Bergersen EP, Knopf BA (eds) Whirling disease workshop proceedings:

Editorial responsibility: Carl Schreck,

Corvallis, Oregon, USA where do we go from here? Colorado Cooperative Fish and Wildlife Research Unit, Fort Collins, CO, p 182-189

Rognlie MC, Knapp SE (1998) Myxobolus cerebralis in Tubifex tubifex from a whirling disease epizootic in Montana. J Parisitol 84:711-713

Schisler GJ (1999) Effects of environmental stressors on juvenile trout exposed to Myxobolus cerebralis. PhD thesis, Colorado State University, Fort Collins, CO

Schisler GJ, Bergersen EP, Walker PG, Wood JS, Epp JK (2001) Comparison of a single round polymerase chain reaction (PCR) and pepsin-trypsin digest (PTD) methods for detection of Myxobolus cerebralis. Dis Aquat Org 45: 109-114

Snieszko SF (1974) The effects of environmental stress on outbreaks of infectious diseases of fishes. J Fish Biol 6: $197-208$

Thompson KG, Nehring RB (2001) A simple technique used to filter and quantify the actinospore of Myxobolus cerebralis and determine its seasonal abundance in the Colorado River. J Aquat Anim Health 12:316-323

Vincent ER (1996) Whirling disease and wild trout: the Montana experience. Fisheries 21:32-33

Walker PG, Nehring RB (1995) An investigation to determine the cause(s) of the disappearance of young wild rainbow trout in the upper Colorado River, in Middle Park, Colorado. Colorado Division of Wildlife, Fort Collins, CO

Wolf K, Markiw ME, Hiltunen JK (1986) Salmonid whirling disease: Tubifex tubifex (Muller) identified as the essential oligochaete in the protozoan life cycle. J Fish Dis 9:83-85

Zendt JS, Bergersen EP (2000) Distribution and abundance of the aquatic oligochaete host Tubifex tubifex for the salmonid whirling disease parasite Myxobolus cerebralis in the upper Colorado River basin. North Am J Fish Manage 20:502-512

Submitted: March 30, 2001; Accepted: November 11, 2001 Proofs received from author(s): April 12, 2002 